\title{
Penerapan Metode Analytical Hierarchy Process (AHP) dalam Pemetaan Potensi Banjir Berbasis Sistem Informasi Geografis (Studi Kasus: Kota Malang, Jawa Timur )
}

Application of the Analytical Hierarchy Process (AHP) Method in Mapping Flood Potentials Based on Geographic Information Systems

(Study Case: Malang City, East Java)

\section{Dwi Ramadhani*, Teguh Hariyanto, Nurwatik}

${ }^{1,2,3}$ Departemen Teknik Geomatika, FTSPK-ITS, Kampus ITS Sukolilo, Surabaya, 60111, Indonesia

*Korespondensi Penulis: dwirmdn@gmail.com

Diterima: 15082021; Diperbaiki: 30102021; Disetujui: 15112021; Dipublikasi: 10012022

\begin{abstract}
Abstrak: Banjir merupakan bencana alam yang paling sering terjadi di Indonesia. Menurut catatan Badan Nasional Penanggulangan Bencana (BNPB), telah terjadi 1080 bencana banjir di Indonesia sepanjang tahun 2020. Pada tanggal 18 Januari 2021, Kota Malang diguyur hujan dengan intensitas tinggi sehingga terjadi bencana banjir dan tanah longsor yang menyebabkan satu orang hilang dan 260 rumah terendam banjir. Dengan adanya bencana tersebut maka diperlukan analisis terhadap penyebab terjadinya banjir serta melakukan pencegahan dan mitigasi dengan pemetaan potensi banjir. Penelitian ini menggunakan metode pembobotan Analytical Hierarchy Process (AHP) dengan narasumber pegawai BAPPEDA Kota Malang, pegawai DPUPRPKP Kota Malang, dan pegawai BPBD Kota Malang. Parameter yang digunakan antara lain ketinggian lahan, kemiringan lereng, jenis tanah, tutupan lahan, histori banjir, curah hujan, dan kerapatan sungai. Hasil dari penelitian ini didapatkan bahwa curah hujan memiliki pengaruh lebih besar terhadap banjir dengan bobot sebesar 50\%, diikuti dengan parameter lain yaitu kemiringan lereng $15 \%$, tutupan lahan 11\%, kerapatan sungai 10\%, histori banjir 7\%, ketinggian lahan 4\%, dan jenis tanah $3 \%$. Kemudian didapatkan tiga kelas potensi banjir yaitu potensi tinggi sebesar $3,04 \mathrm{~km}^{2}$, potensi sedang sebesar $90,42 \mathrm{~km}^{2}$, dan potensi rendah sebesar 9,41 $\mathrm{km}^{2}$. Wilayah yang berpotensi tinggi terhadap banjir adalah Kelurahan Kelurahan Arjosari, Purwodadi, Pandanwangi, Purwantoro, Sawojajar, Bunulrejo, Blimbing, Jatimulyo, Tlogomas, Lowokwaru, Dinoyo, Ketawanggede, dan Penanggungan.
\end{abstract}

Copyright () 2022 Geoid. All rights reserved.

\begin{abstract}
Floods are the most frequent natural disasters in Indonesia. According to the records of the National Disaster Management Agency (BNPB), there have been 1080 flood disasters in Indonesia throughout 2020. On January 18, 2021, the city of Malang was drenched in heavy rain, resulting in floods and landslides that left one person missing and 260 houses submerged. flood. With this disaster, it is necessary to analyze the causes of flooding and carry out prevention and mitigation by mapping the potential for flooding. This study uses the Analytical Hierarchy Process (AHP) weighting method with the resource persons of BAPPEDA Malang City employees, Malang City DPUPRPKP employees, and Malang City BPBD employees. Parameters used include land height, slope, soil type, land cover, flood history, rainfall, and river density. The results of this study found that rainfall has a greater influence on flooding with a weight of 50\%, followed by other parameters, namely slope $15 \%$, land cover $11 \%$, river density $10 \%$, flood history $7 \%$, land height 4\%, and 3\% soil type. Then obtained three classes of flood potential, namely high potential of $3.04 \mathrm{~km}^{2}$, medium potential of $90.42 \mathrm{~km}^{2}$, and low potential of $9.41 \mathrm{~km}^{2}$. Areas that have high potential for flooding are Arjosari, Purwodadi, Pandanwangi, Purwantoro, Sawojajar, Bunulrejo, Blimbing, Jatimulyo, Tlogomas, Lowokwaru, Dinoyo, Ketawanggede, and Penanggungan villages..
\end{abstract}

Kata kunci: Analytical Hierarchy Process; banjir; SIG 
Cara untuk sitasi: Ramadhani, D., Hariyanto, T., \& Nurwatik. (2021). Penerapan Metode Analytical Hierarchy Process (AHP) dalam Pemetaan Potensi Banjir Berbasis Sistem Informasi Geografis. Geoid, 17(1), 72 - 80.

\section{Pendahuluan}

Bencana banjir merupakan suatu kejadian alam yang sulit diduga karena datang secara tiba-tiba dengan periodisitas (berulang secara berkala) yang tidak menentu, kecuali daerah- daerah yang sudah menjadi langganan terjadinya banjir tahunan di musim penghujan. Bencana banjir tersebut berdampak merugikan bagi masyarakat yang tinggal di kawasan yang rawan banjir (Matondang 2013). Banjir merupakan kondisi dimana pada daerah yang secara topografis dan geomorfologis bersifat kering (bukan daerah rawa) tergenang oleh air yang terjadi akibat tingkat drainase tanah yang telah jenuh dalam menampung air dan kemampuan infiltrasi air ke dalam tanah yang mencapai batas maksimum, biasanya terjadi pada daerah-daerah yang memiliki topografi lebih rendah (cekungan), dengan tingkat curah hujan daerah yang cukup tinggi. Selain itu terjadinya banjir dapat disebabkan oleh limpasan air permukaan (runoff) yang meluap dan volumenya melebihi kapasitas sistem drainase atau sistem aliran sungai (Seyhan 2008).

Menurut Bakornas (2007) kejadian dan korban bencana banjir menempati urutan pertama di dunia dengan persentase sebesar 55\%. Banjir juga merupakan bencana alam yang paling sering terjadi di Indonesia (Wijaya dkk. 2018). Menurut catatan Badan Nasional Penanggulangan Bencana (BNPB), telah terjadi 1080 bencana banjir di Indonesia sepanjang tahun 2020 (BNPB 2021).

Secara geografis Kota Malang merupakan kota yang terletak di dataran tinggi yang sekitarnya di kelilingi oleh beberapa gunung, antara lain gunung Anjasmoro, gunung Arjuno, Gunung Argopuro, Gunung Bromo, Gunung Welirang, Gunung Kawi. Kota Malang saat ini menjadi kota yang mulai padat dengan jumlah penduduk. Hal ini dapat dilihat dari jumlah perumahan yang mulai marak di Kota Malang. Bahkan area daerah aliran sungai pun kini telah banyak ditempati perumahan-perumahan yang padat penduduk. Hal tersebut mengakibatkan jumlah ruang terbuka hijau untuk penyerapan air hujan di Kota Malang menjadi berkurang (Hayat 2014). Akibatnya Kota Malang sering menjadi langganan banjir, terlebih lagi ketika hujan tiba. Dari lima kecamatan yang ada di daerah Malang yaitu Kecamatan Blimbing, Sukun, Kedungkandang, Lowokwaru, dan Klojen semua pernah menjadi langganan banjir.

Pada penelitian ini akan dilakukan analisis terhadap potensi banjir di Kota Malang menggunakan beberapa kriteria yakni ketinggian lahan, kemiringan lereng, jenis tanah, penggunaan lahan, histori kejadian banjir, curah hujan, dan kerapatan sungai. Penelitian ini juga memanfaatkan pembobotan Analytical Hierarchy Process (AHP) dan Sistem Informasi Geografis (SIG) dalam proses pemetaan.

\section{Data dan Metode}

Penelitian ini dilakukan di Kota Malang, Provinsi Jawa Timur yang berada pada $07^{\circ} 46^{\prime} 48^{\prime \prime}$ - $08^{\circ} 46^{\prime} 42^{\prime \prime}$ Lintang Selatan dan $112^{\circ} 31^{\prime} 42^{\prime \prime}-112^{\circ} 48^{\prime} 48^{\prime \prime}$ Bujur Timur, dengan luas wilayah 110,06 $\mathrm{km}^{2}$. Data yang digunakan adalah data DEMNAS Kota Malang, data curah hujan, data jenis tanah, data jaringan sungai, data tutupan lahan, data histori kejadian banjir, data - data penilaian pembobotan AHP yang berasal dari responden. Untuk peralatan yang digunakan dalam penelitian ini adalah perangkat keras laptop, perangkat lunak pengolah data spasial (ArcGIS), pengolah kata dan angka (Microsoft Office), perangkat lunak pengambilan keputusan (Super Decisions). 


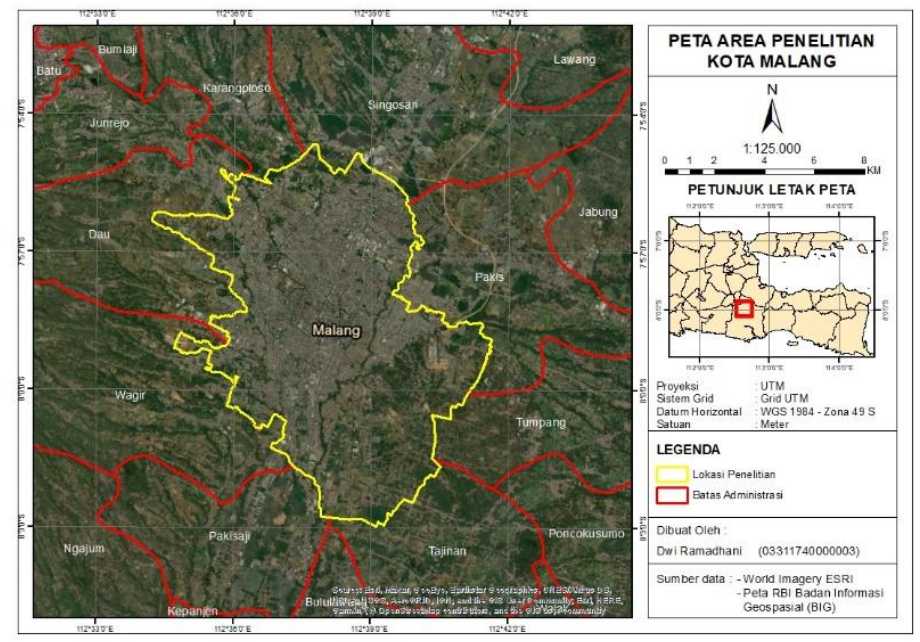

Gambar 1. Peta Lokasi Penelitian Kota Malang, Jawa Timur

Pada pengolahan data, Data DEMNAS diperoleh dari situs resmi BIG digunakan sebagai data acuan untuk pembuatan peta ketinggian lahan dan kemiringan lereng (slope). Data curah hujan diperoleh melalui situs resmi milik Badan Meteorologi, Klimatologi dan Geofisika Indonesia, yakni data dari Stasiun BMKG Karangploso dan Stasiun Karangkates dilakukan perhitungan jumlah curah hujan dalam setahun kemudian dilakukan interpolasi dengan metode IDW. Data vektor sungai yang diperoleh dari BPBD Kota Malang kemudian diolah menggunakan software ArcGIS menggunakan tool line density sehingga didapatkan nilai kerapatan sungai. Data hasil pengisian kuesioner oleh responden diolah menggunakan metode pembobotan AHP melalui software Super Decisions.

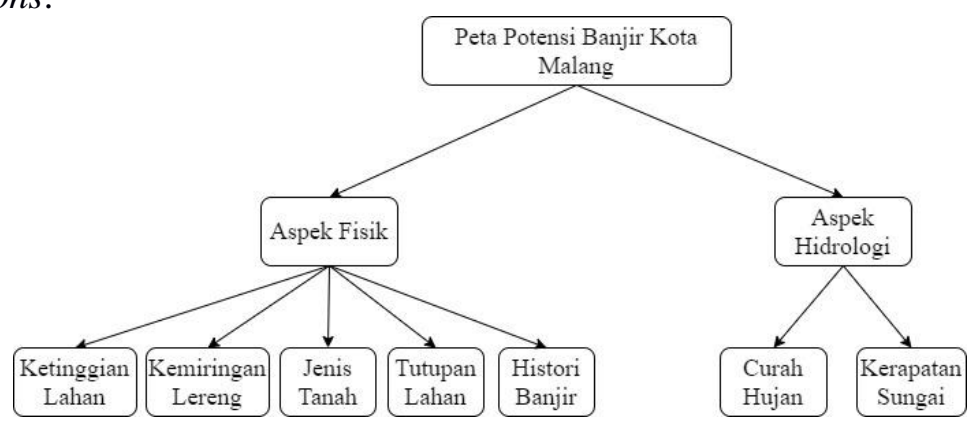

Gambar 2. Diagram Hirarki Penelitian

Setelah dilakukan pengolahan pada masing-masing parameter, selanjutnya dilakukan proses skoring. Pemberian skor pada masing-masing parameter tergantung pada pengaruhnya terhadap bencana banjir. Semakin tinggi skor pada suatu variabel parameter tersebut, maka semakin tinggi pengaruhnya.

Tabel 1. Klasifikasi Histori Kejadian Banjir (Prayudhatama 2017)

\begin{tabular}{ccc}
\hline No. & Jumlah Kejadian & Skor \\
\hline 1. & $0-5$ & 1 \\
\hline 2. & $6-20$ & 2 \\
\hline 3. & $>20$ & 3 \\
\hline
\end{tabular}

Tabel 2. Klasifikasi Ketinggian Lahan (Junivan, dkk. 2018)

\begin{tabular}{ccc}
\hline No. & Ketinggian $(\mathbf{m})$ & Skor \\
\hline 1. & $0-20$ & 5 \\
\hline 2. & $21-50$ & 4 \\
\hline 3. & $51-100$ & 3 \\
\hline 4. & $101-300$ & 2 \\
\hline 5. & $>300$ & 1 \\
\hline
\end{tabular}


Tabel 3. Klasifikasi Kemiringan Lereng (Wismarini dan Sukur 2015)

\begin{tabular}{ccc}
\hline No. & Kemiringan $(\%)$ & Skor \\
\hline 1. & $0-2$ & 5 \\
\hline 2. & $>2-15$ & 4 \\
\hline 3. & $>15-25$ & 3 \\
\hline 4. & $>25-40$ & 2 \\
\hline 5. & $>40$ & 1 \\
\hline
\end{tabular}

Tabel 4. Klasifikasi Jenis Tanah (Permen PU 2007)

\begin{tabular}{|c|c|c|c|}
\hline No. & Jenis Tanah & Infiltrasi & Skor \\
\hline 1. & $\begin{array}{l}\text { Aluvial, Planosol, Hidromorf } \\
\text { kelabu, Laterik air tanah }\end{array}$ & Tidak Peka & 5 \\
\hline 2. & Latosol & Agak peka & 4 \\
\hline 3. & $\begin{array}{c}\text { Tanah hutan coklat, Tanah } \\
\text { mediteran }\end{array}$ & $\begin{array}{l}\text { Kepekaan } \\
\text { sedang }\end{array}$ & 3 \\
\hline 4. & $\begin{array}{c}\text { Andosol, Laterik, Grumosol, } \\
\text { Podsol, Podsolic }\end{array}$ & Peka & 2 \\
\hline 5. & $\begin{array}{l}\text { Regosol, Litosol, Organosol, } \\
\text { Renzina }\end{array}$ & Sangat peka & 1 \\
\hline
\end{tabular}

Tabel 5. Klasifikasi Curah Hujan (Primayuda 2006)

\begin{tabular}{ccc}
\hline No. & Jumlah Curah Hujan (mm/tahun) & Skor \\
\hline 1. & $<1000$ & 1 \\
\hline 2. & $1000-1500$ & 2 \\
\hline 3. & $1500-2000$ & 3 \\
\hline 4. & $2000-2500$ & 4 \\
\hline 5. & $>2500$ & 5 \\
\hline
\end{tabular}

Tabel 6. Klasifikasi Tutupan Lahan (Wismarini dan Sukur 2015

\begin{tabular}{ccc}
\hline No. & Tipe Tutupan Lahan & Skor \\
\hline 1. & Hutan & 1 \\
\hline 2. & Rawa / Danau / Tambak & 2 \\
\hline 3. & Lahan Terbuka & 3 \\
\hline 4. & Sawah / Pertanian & 4 \\
\hline 5. & Fasilitas dan Prasarana & 5 \\
\hline 6. & Permukiman / Industri / Perkantoran & 6 \\
\hline
\end{tabular}

Tabel 7. Klasifikasi Kerapatan Sungai (Linsley dkk. 1959 dalam Matondang 2013)

\begin{tabular}{cccc}
\hline No. & $\begin{array}{c}\text { Kerapatan Sungai } \\
\left(\mathbf{K m} / \mathbf{K m}^{\mathbf{2}}\right)\end{array}$ & Deskripsi & Skor \\
\hline 1. & $<0,62$ & Menggenang & 5 \\
\hline 2. & $0,62-1,44$ & Agak menggenang & 4 \\
\hline 3. & $1,45-2,27$ & Sedang & 3 \\
\hline 4. & $2.28-3,10$ & Agak Kering & 2 \\
\hline 5. & $>3,10$ & Kekeringan & 1 \\
\hline
\end{tabular}

Setelah proses skoring kemudian dilakukan proses overlay terhadap ketujuh parameter dengan metode weighted overlay untuk mendapatkan potensi banjir. Penulis mengklasifikasikan potensi banjir menjadi tiga kelas yaitu rendah, sedang, dan tinggi yang mengacu pada Indeks Risiko Bencana Indonesia.

\section{Hasil dan Pembahasan}

Pada penelitian ini yang menjadi responden dalam pengisian kuesioner metode AHP yaitu pegawai Badan Penanggulangan Bencana Daerah (BPBD) Kota Malang, pegawai Badan Perencanaan Pembangunan Daerah (BAPPEDA) Kota Malang. dan pegawai Dinas Pekerjaan Umum, Penataan Ruang, Perumahan, dan Kawasan 
Permukiman (DPUPRPKP) Kota Malang. Hasil dari pembobotan Analytical Hierarchy Process (AHP) bahwa aspek hidrologi mempunyai pengaruh yang lebih besar terhadap banjir dengan bobot $60 \%$ dibanding aspek fisik. Sedangkan parameternya menunjukkan bahwa curah hujan mempunyai pengaruh yang paling besar terhadap banjir dengan bobot $50 \%$.

\begin{tabular}{|c|c|c|c|}
\hline Keterangan & Parameter & Bobot & $\begin{array}{l}\text { Total } \\
\text { Bobot }\end{array}$ \\
\hline \multirow{2}{*}{ Kriteria } & Fisik & $40 \%$ & \multirow{2}{*}{$100 \%$} \\
\hline & Hidrologi & $60 \%$ & \\
\hline \multicolumn{4}{|c|}{$\Lambda=2, \mathrm{CI}=0, \mathrm{CR}=0$} \\
\hline \multirow{5}{*}{$\begin{array}{l}\text { Sub Kriteria } \\
\text { Fisik }\end{array}$} & Kemiringan Lereng & $15 \%$ & \multirow{5}{*}{$40 \%$} \\
\hline & Ketinggian Lahan & $4 \%$ & \\
\hline & Jenis Tanah & $3 \%$ & \\
\hline & Tutupan Lahan & $11 \%$ & \\
\hline & Histori Banjir & $7 \%$ & \\
\hline \multicolumn{4}{|c|}{$\Lambda=5,06, \mathrm{CI}=0,015, \mathrm{CR}=0,013$} \\
\hline \multirow{2}{*}{$\begin{array}{l}\text { Sub Kriteria } \\
\text { Hidrologi }\end{array}$} & Curah Hujan & 0,5 & \multirow{2}{*}{$60 \%$} \\
\hline & Kerapatan Sungai & 0,1 & \\
\hline \multicolumn{4}{|c|}{$\Lambda=2, \mathrm{CI}=0, \mathrm{CR}=0$} \\
\hline
\end{tabular}

Parameter ketinggian mempunyai pengaruh terhadap terjadinya banjir. Berdasarkan sifat air yang mengalir mengikuti gaya gravitasi yaitu mengalir dari daerah tinggi ke daerah rendah. Dimana daerah yang mempunyai ketinggian yang lebih tinggi lebih berpotensi kecil untuk terjadi banjir dan sebaliknya. Pemberian skor pada kelas ketinggian yang lebih tinggi lebih kecil daripada skor untuk kelas ketinggian yang rendah. Wilayah di Kota Malang memiliki ketinggian dengan rentang 380 - 699 meter.

Kemiringan lereng mempengaruhi jumlah dan kecepatan limpasan permukaan, drainase permukaan, penggunaan lahan dan erosi. Diasumsikan semakin landai kemiringan lerengnya, maka aliran limpasan permukaan akan menjadi lambat dan kemungkinan terjadinya banjir menjadi besar. Wilayah di Kota Malang yang memiliki kemiringan lereng sebesar $0-2 \%$ seluas $22,45 \mathrm{~km} 2$, lebih dari $2-15 \%$ seluas $77,85 \mathrm{~km}^{2}$, lebih dari $15-25 \%$ seluas $7 \mathrm{~km}^{2}$, lebih dari $25-40 \%$ seluas $0,64 \mathrm{~km}^{2}$, dan lebih dari $40 \%$ seluas $0,01 \mathrm{~km}^{2}$. Hal ini berarti bahwa berdasarkan parameter kemiringan lereng maka 20,4\% wilayah di Kota Malang memungkinkan terjadi genangan atau banjir.

Di wilayah Kota Malang, jenis tanah didominasi oleh aluvial kelabu tua dengan total luas $69,99 \mathrm{~km}^{2}$, jenis tanah asosiasi latosol coklat kemerahan, latosol coklat seluas $20,36 \mathrm{~km}^{2}$, jenis tanah mediteran coklat kemerahan seluas $16,79 \mathrm{~km}^{2}$, jenis tanah asosiasi latosol coklat dan regosol kelabu seluas $3,85 \mathrm{~km}^{2}$, dan regosol coklat seluas $0,01 \mathrm{~km}^{2}$. Tanah regosol coklat terdapat hanya di sebagian kecil wilayah Kelurahan Tlogowaru. Tanah aluvial memiliki tekstur yang halus dibandingkan jenis tanah lainnya sehingga 63,59\% wilayah di Kota Malang memiliki potensi kejadian banjir yang tinggi jika didasarkan pada parameter jenis tanah.

Sementara itu, hasil klasifikasi tutupan lahan di Kota Malang didominasi oleh permukiman, industri, dan perkantoran dengan luas sebesar $61,65 \mathrm{~km} 2$, sawah seluas $34,35 \mathrm{~km} 2$, lahan terbuka seluas $6,91 \mathrm{~km} 2$, serta fasilitas dan prasarana seluas $6 \mathrm{~km} 2$. Peta tutupan lahan Kota Malang. Hal ini berarti bahwa berdasarkan parameter tutupan lahan maka 56,01\% wilayah di Kota Malang berpotensi tinggi mengalami banjir.

Berdasarkan hasil interpolasi dengan metode IDW (Interpolation Distance Weighted) curah hujan di Kota Malang terbagi menjadi satu kelas yakni kisaran 2012-2026 mm per tahun. Hal ini dikarenakan pada stasiun BMKG Karangkates dan Karangploso memiliki record data yang hampir sama per bulannya. Sehingga ketika 
dilakukan IDW, Kota Malang yang berada di antara kedua stasiun ini juga memiliki hasil yang sama yaitu pada kelas $2000-2500 \mathrm{~mm} / \mathrm{tahun}$.

Berdasarkan data histori banjir, 30 dari 57 kelurahan di Kota Malang tidak mengalami bencana banjir. Wilayah yang paling sering mengalami banjir adalah Kelurahan Purwodadi dan Lowokwaru.

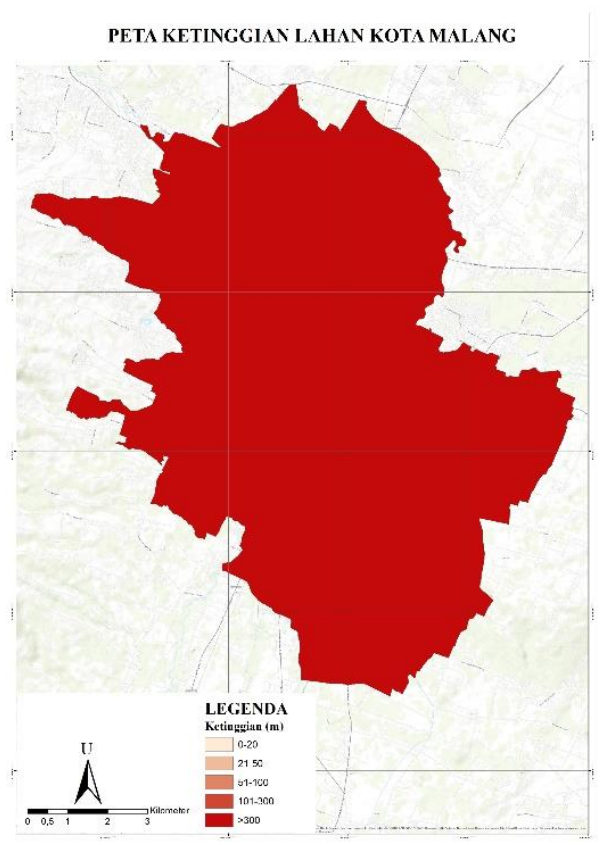

Gambar 3. Peta Ketinggian Lahan

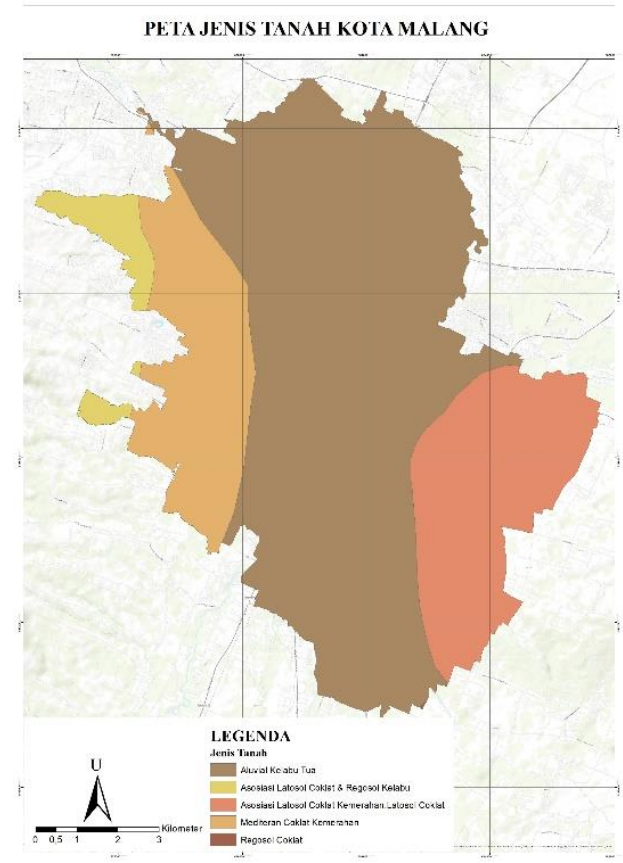

Gambar 5. Peta Jenis Tanah

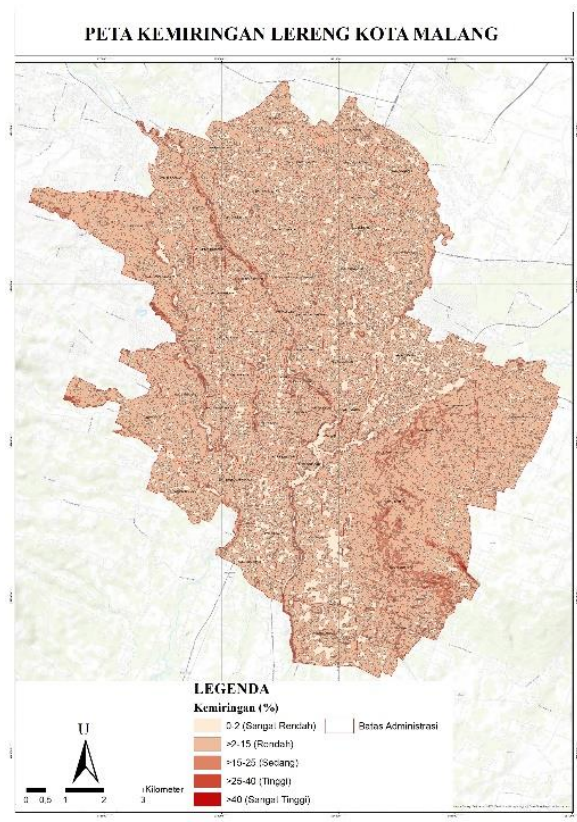

Gambar 4. Peta Kemiringan Lereng

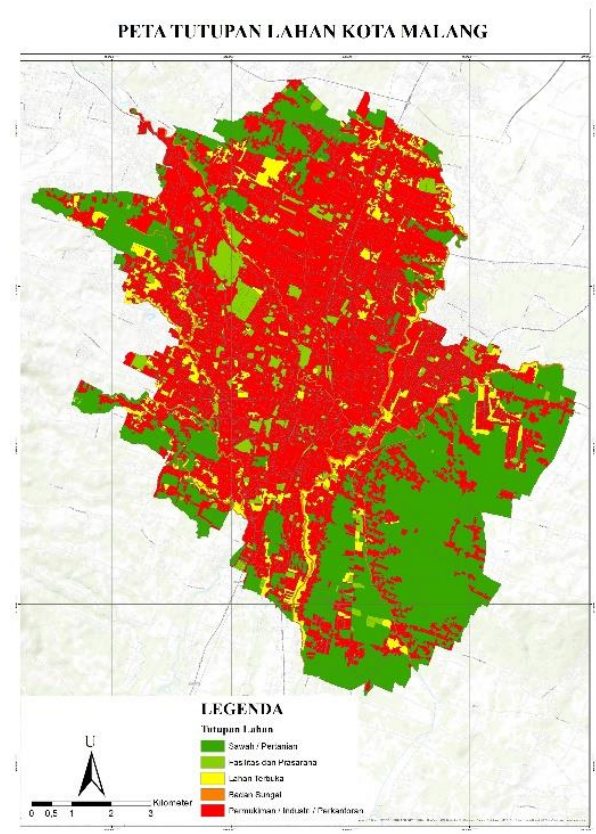

Gambar 6. Peta Tutupan Lahan 


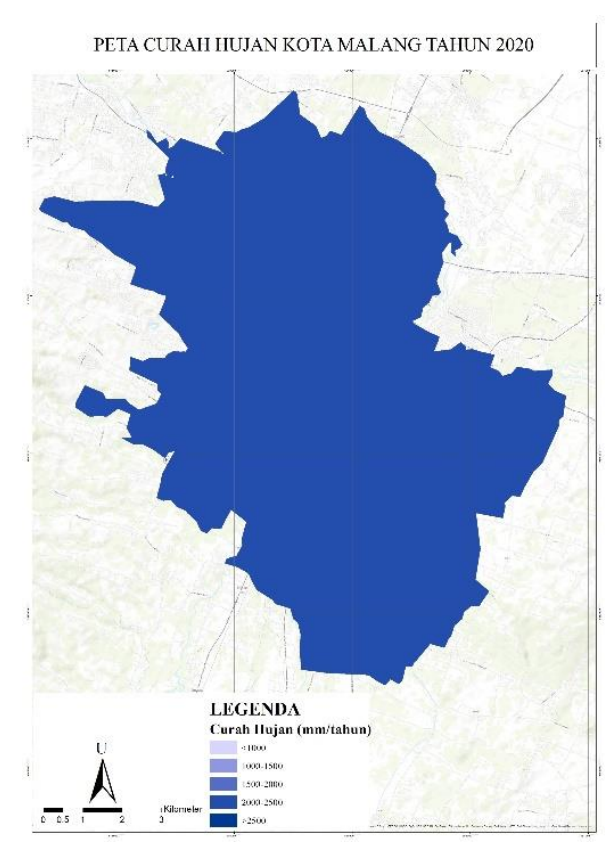

Gambar 7. Peta Curah Hujan

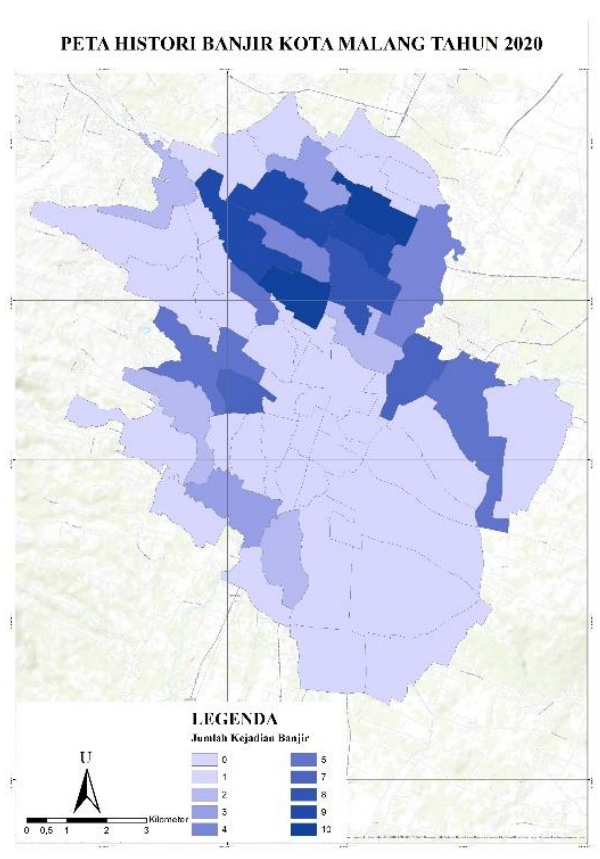

Gambar 8. Peta Histori Banjir

Kerapatan sungai di Kota Malang berada pada rentang nilai 0-6,4 km/ $/ \mathrm{km}^{2}$. Hampir 50\% wilayah Kota Malang memiliki nilai kerapatan sungai yang rendah yang berarti mengalami penggenangan. Wilayah dengan kerapatan sungai yang tinggi (kekeringan) berada pada Kelurahan Bandungrejosari, Mulyorejo, Pisangcandi, Sukun, Kotalama, Kedungkandang, Buring, Polehan, Jodipan, Sawojajar, dan Pandanrejo.

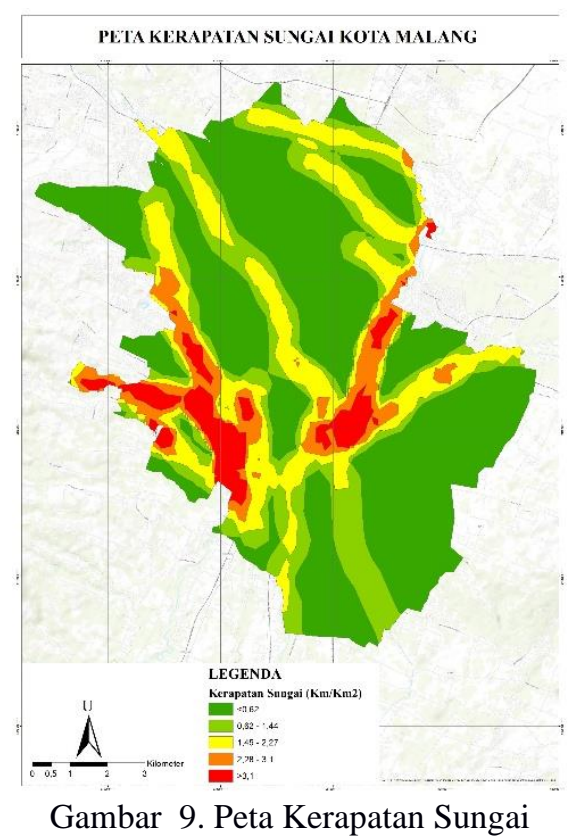

Hampir seluruh wilayah di Kota Malang $(82,15 \%)$ berpotensi sedang mengalami banjir. Dari 57 kelurahan yang ada, 13 di antaranya berpotensi tinggi mengalami banjir. Kelurahan yang memiliki wilayah terluas dengan potensi banjir tinggi adalah Kelurahan Purwodadi. Hal ini dibuktikan dengan data kejadian banjir tahun 2020, bahwa Kelurahan Purwodadi memiliki 10 sebaran titik banjir dalam waktu satu tahun. 
Tabel 9. Sebaran Potensi Banjir

\begin{tabular}{cll}
\hline Potensi Banjir & Luas $\left(\mathrm{km}^{2}\right)$ & \multicolumn{1}{c}{$\begin{array}{c}\text { Lokasi } \\
\text { (Kelurahan) }\end{array}$} \\
\hline \multirow{2}{*}{ Rendah } & 9,40755 & $\begin{array}{l}\text { Kedungkandang, Buring, Wonokoyo, } \\
\text { Tlogowaru, Arjowinangun, Bumiayu, } \\
\text { Bakalankrajan, Mulyorejo, Merjosari, } \\
\text { Karangbesuki, Bandungrejosari }\end{array}$ \\
\hline Sedang & 90,41822 & Seluruh Kelurahan di wilayah Kota Malang \\
\hline \multirow{2}{*}{ Tinggi } & & $\begin{array}{l}\text { Arjosari, Purwodadi, Pandanwangi, Purwantoro, } \\
\text { Sawojajar, Bunulrejo, Blimbing, Jatimulyo, } \\
\text { Tlogomas, Lowokwaru, Dinoyo, Ketawanggede, } \\
\end{array}$ \\
& 3,038009 & Penanggungan \\
\hline
\end{tabular}
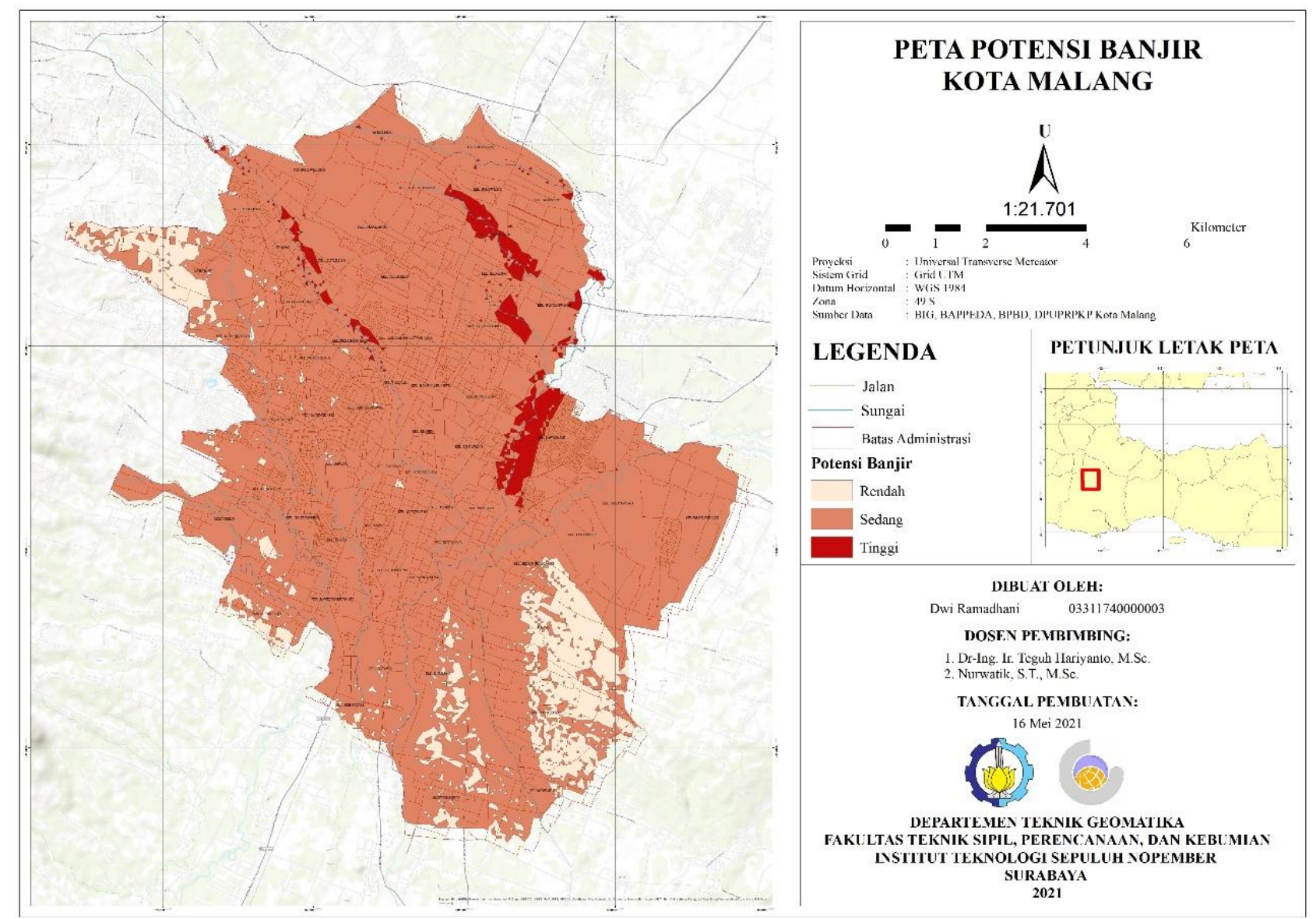

Gambar 10. Peta Potensi Banjir

\section{Kesimpulan}

Dari pembahasan di atas, dapat diambil kesimpulan bahwa dari ketujuh parameter yang digunakan, parameter curah hujan memiliki pengaruh paling besar terhadap banjir dengan bobot sebesar 50\%. Hasil ini didapatkan dari perhitungan metode Analytical Hierarchy Process dengan nilai yang didapat dari 3 narasumber. Sedangkan untuk hasil akhir dari penelitian ini yaitu peta potensi banjir didapatkan tiga kelas potensi sesuai dengan Indeks Risiko Bencana Indonesia yaitu potensi rendah, sedang, dan tinggi. Masing-masing tingkat potensi mempunyai luas sebesar $9,40755 \mathrm{~km}^{2}$ untuk potensi rendah, $90,41822 \mathrm{~km}^{2}$ untuk potensi sedang, dan $3,038009 \mathrm{~km}^{2}$ untuk potensi tinggi. Wilayah dengan potensi banjir tinggi berada pada Kelurahan Arjosari, Purwodadi. 


\section{Ucapan Terimakasih}

Penulis mengucapkan terima kasih kepada Badan Perencanaan Pembangunan Daerah (BAPPEDA) dan Badan Penanggulangan Bencana Daerah (BPBD) Kota Malang yang telah memberikan data spasial dan pengisian kuesioner yang digunakan dalam penelitian kali ini. Serta pegawai DPUPRPKP yang telah menyempatkan waktunya sebagai responden dalam penelitian ini.

\section{Daftar Pustaka}

Bakornas PB. 2007. Pengenalan Karakteristik Bencana dan Upaya Mitigasinya di Indonesia. Jakarta: Badan Nasional Penanggulangan Bencana.

Badan Nasional Penanggulangan Bencana. 2013. Indeks Risiko Bencana Indonesia. Jakarta: BNPB.

Badan Nasional Penanggulangan Bencana. 2021. Kejadian Bencana Tahun 2020. <URL: https://www.bnpb.go.id/infografis/kejadian-bencana-tahun-2020>. Dikunjungi pada 12 Januari 2021, jam 19.30.

Junivan, dkk. 2018. Analisis Potensi Banjir di Kota Denpasar Menggunakan Metode Analytical Hierarchy Process. Majalah Ilmiah Teknologi Elektro, 17(2), pp.227-236.

Matondang, J.P. 2013. “Analisis Zonasi Daerah Rentan Banjir Dengan Pemanfaatan Sistem Informasi Geografis (SIG) (Studi Kasus: Kota Kendal dan Sekitarnya). Jurnal Geodesi Universitas Diponegoro.Volume 2, Nomor 2, Tahun 2013 (ISSN:2337-845X)

Peraturan Menteri Pekerjaan Umum No.41/PRT/M/2007 Tentang Pedoman Kriteria Teknis Kawasan Budidaya.

Prayudhatama, A., 2017. Kajian Bahaya dan Kerentanan Banjir di Yogyakarta. Tugas Akhir. Yogyakarta: Universitas Muhammadiyah Yogyakarta.

Primayuda A, 2006. Pemetaan Daerah Bahaya dan Resiko Banjir Menggunakan Sistem Informasi Geografis: studi kasus Kabupaten Trenggalek, Jawa Timur. Tugas Akhir. Bogor: Fakultas Pertanian, Institut Pertanian Bogor.

Seyhan, E. 2008. Dasar-dasar Hidrologi. Yogyakarta.

Wismarini, T.D. dan Sukur, M., 2015. Penentuan tingkat kerentanan banjir secara geospasial. Dinamik, 20(1). 